\title{
Tax Incentives: From an Investment, Tax, and Sustainable Development Perspective
}

\author{
Irma Johanna Mosquera Valderrama
}

\section{Contents}

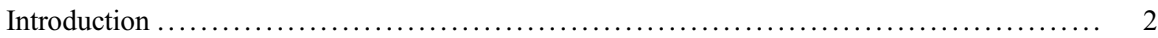

Tax Incentives to Promote Economic Growth and to Attract Foreign Direct Investment ..... 4

An Overview of Tax Incentives .......................................... 4

Tax Incentives in Developing Countries to Attract FDI .......................... 6

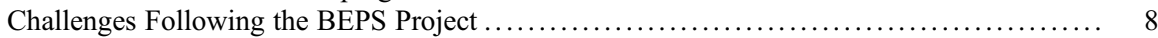

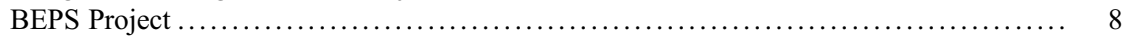

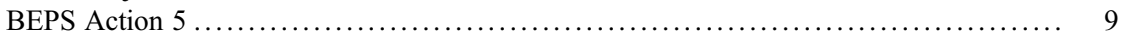

Tax Incentives in Developing Countries After BEPS ........................... 12

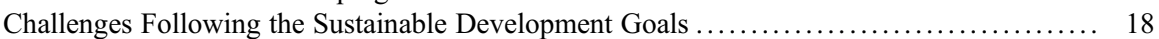

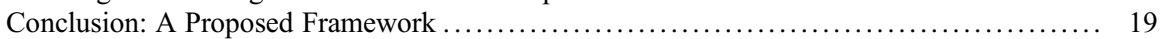

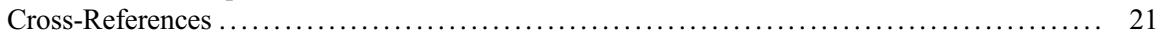

\begin{abstract}
The aim of this chapter is twofold. The first aim is to provide an overview of tax incentives in developing countries to attract foreign direct investment (FDI) and the challenges for developing countries following the introduction of the OECDG20 project to tackle base erosion and profit shifting (BEPS) by multinationals. The use of tax incentives has been discussed extensively by scholars and international organizations with different views on the usefulness of tax incentives to promote economic growth and to attract FDI. This chapter argues that tax incentives in developing countries are needed to contribute to development of underdeveloped geographical areas and specific economic sectors or industries. This chapter also argues that developing countries should have a framework to
\end{abstract}

I. J. Mosquera Valderrama ( $\square$ )

Faculty of Law, Institute of Tax Law and Economics, Leiden University, Leiden, The Netherlands e-mail: i.j.mosquera.valderrama@law.leidenuniv.nl 
evaluate the usefulness of tax incentives in light of the Sustainable Development Goals (SDGs). This framework should be designed by each country and, if possible, taking into account the practices of other countries in the region so that countries can also exchange best practices. Therefore, the second aim of this chapter is to propose this evaluative framework.

\section{Keywords}

Investment $\cdot$ Tax incentives $\cdot$ Tax $\cdot$ Development $\cdot$ SDG

\section{Introduction}

Tax incentives aim to promote economic activities and to improve the economic growth in countries. Tax incentives may have different aims (i) for developed countries, to promote export, research, and development activities, and (ii) for developing countries, to attract foreign direct investment and to improve economic conditions in a specific sector/region. The scope of application can be geographical (based on location, e.g., free trade zones) or specific for a sector/industry (e.g., hotel services, natural resources).

The use of tax incentives to promote foreign direct investment has been discussed extensively in literature. ${ }^{1}$ For instance, in 2013, Brauner argued that tax incentives do not promote economic growth, and therefore tax incentives are not the right tool to attract foreign direct investment. ${ }^{2}$ Further studies have been carried out by scholars to address the effectiveness of tax incentives in attracting investment. ${ }^{3}$

\footnotetext{
${ }^{1}$ Van Parys S (2012) The effectiveness of tax incentives in attracting investment: evidence from developing countries. Reflets et perspectives de la vie économique LI(3):129-141. https://doi.org/ $10.3917 /$ rpve.513.0129

${ }^{2}$ Brauner Y (2013) The future of tax incentives for developing countries. In: Brauner Y, Stewart M (eds) Tax law and development. Edward Elgar Publishing, Cheltenham, p 26

${ }^{3}$ Stausholm SN (2017) Rise of ineffective incentives: new empirical evidence on tax holidays in developing countries. Available at https://doi.org/10.17605/OSF.IO/4SN3K. Accessed 6 Nov 2019; Van Parys S (2012) The effectiveness of tax incentives in attracting investment: evidence from developing countries. Reflets et perspectives de la vie économique LI(3):129-141. https://doi.org/ 10.3917/rpve.513.0129; Choon NC, Whalley J (1995) Patterns in investment tax incentives among developing countries. In: Shah A (ed) Fiscal incentives for investment in developing countries. The World Bank, Washington, DC, pp 437-454; Raff H, Srinivasan K (1998) Tax incentives for importsubstituting foreign investment: does signaling play a role? J Pub Econ 67(2):167-193, 168; Columbia Center on Sustainable Investment (CCSI) (2018) Rethinking international investment governance: principles for the 21st century. Available at http:/ccsi.columbia.edu/2018/08/13/ rethinking-international-investment-governance-principles-for-the-21st-century/ Accessed 6 Nov 2019; OECD (n.d.) Principles to enhance the transparency and governance of tax incentives for investment in developing countries. Available at http://www.oecd.org/ctp/tax-global/transparencyand-governance-principles.pdf. Accessed 6 Nov 2019
} 
In a 2015 report, international organizations (i.e., IMF, OECD, WB, and the UN) also addressed the use of "wasteful" tax incentives ${ }^{4}$ for low-income countries and the need to change these incentives to improve the effectiveness and efficiency. ${ }^{5}$ In a 2018 report, the UN and the Regional Tax Organization CIAT recommends to developing countries to be careful when drafting tax incentives since the priority should be to correct the deficiencies in the design of the tax system rather than providing investors with additional tax benefits. ${ }^{6}$ The OECD and the Regional Tax Organization ATAF addressed the use of exchange of information to detect the potential abuse of tax incentives in developing countries. ${ }^{7,8}$

The World Bank in the 2017/2018 Global Investment Competitiveness Report ${ }^{9}$ also addressed the need for countries to maximize the development impact of foreign direct investment in order to meet the Sustainable Development Goals (SDGs). Scholars have also addressed the need to design tax incentives to attract sustainable investment that contributes to achieve the UN SDGs mainly SDG 17.1 on domestic resource mobilization (DRM) and 17.16 on global partnerships for sustainable development. ${ }^{10}$

Furthermore, in the framework of the OECD-G20 Project and its 15 Actions to tackle base erosion and profit shifting ("BEPS") by multinationals, the use of tax incentives in the form of preferential tax regimes for geographically mobile business income (such as income from the provision of intangibles, and financial services), which present a risk of BEPS activity, was addressed in the framework of BEPS

\footnotetext{
${ }^{4}$ Reference was made to "wasteful incentives" stating that even though this concept is not always well-defined. In the paper, these organizations used the cost-benefit analysis to identify whether tax incentives are desirable or not.

${ }^{5}$ IMF, OECD, UN et al (2015) Options for low income countries' effective and efficient use of tax incentives for investment: a report to the G-20 development working group by the IMF, OECD, UN and World Bank, p 9. Available at https://doi.org/10.1596/22923. Accessed 6 Nov 2019

${ }^{6}$ UN-CIAT (2018) Design and assessment of tax incentives in developing countries: selected issues and a country experience, iii. Available at https://www.ciat.org/Biblioteca/Estudios/2018_design_ assessment_tax_incentives_UN_CIAT.pdf. Accessed 6 Nov 2019

${ }^{7}$ CIAT (Inter-American Centre of Tax Administrations) and ATAF (African Tax Administration Forum) are regional tax organizations which members are developing countries (CIAT, Caribbean, Middle and South America, and some African Countries; ATAF (African Countries)).

${ }^{8}$ OECD-ATAF (2013) A practical guide for exchange of information for developing countries. Available at http://www.oecd.org/tax/tax-global/practical_guide_exchange_of_information.pdf Accessed 6 Nov 2019

${ }^{9}$ World Bank (2018) Global investment competitiveness report 2017/2018: foreign investor perspectives and policy implications. World Bank Group, Washington, DC. Available at http:// documents.worldbank.org/curated/en/169531510741671962/Global-investment-competitivenessreport-2017-2018-foreign-investor-perspectives-and-policy-implications. Accessed 6 Nov 2019

${ }^{10}$ Mosquera Valderrama IJ, Lesage D, Lips W (2018) Tax and development: the link between international taxation, the base erosion profit shifting project and The 2030 sustainable development agenda. UNU-CRIS working paper no. W-2018/3. Available at http://cris.unu.edu/sites/cris.unu. edu/files/W-2018-4.pdf. Accessed 6 Nov 2019
} 
Action 5 dealing with harmful tax practices. ${ }^{11}$ At the time of writing (November 2019), more than 135 jurisdictions have committed to review their preferential tax regimes and to amend or abolish if the regime is regarded as harmful tax practice.

These developments have consequences for lawmakers in the drafting of tax incentives. Therefore, a new framework for tax incentives in developing countries that contribute to sustainable investment and to achieve the SDGs should be introduced. In order to develop this framework, this chapter is structured as follows. The second section addresses the type of tax incentives that countries introduce to promote economic activities and to attract foreign direct investment. The third section further explores the manifold challenges of BEPS implementation. The fourth section introduces the challenges for developing countries to change their tax incentives following the BEPS and 2030 SDGs including the 2030 Agenda. Thereafter, the proposed new framework will be presented in section "Conclusion: A Proposed Framework".

\section{Tax Incentives to Promote Economic Growth and to Attract Foreign Direct Investment}

Developing countries are introducing tax incentives to promote economic growth and to attract foreign direct investment. The type and number of incentives differ between developed and developing countries and also within developing countries. Therefore, section "An Overview of Tax Incentives" will provide a definition and an overview of tax incentives. Thereafter section "Tax Incentives in Developing Countries to Attract FDI" will address the challenges of developing countries to attract FDI, to control the FDI, and to provide transparency and accountability in the granting of tax incentives.

\section{An Overview of Tax Incentives}

The focus of this contribution is on tax incentives applicable to corporations carrying out cross-border (foreign) direct investment. However, it is important to keep in mind that there are also other incentives introduced by countries to reduce inequalities among individuals (e.g., personal tax credits, single-parent families) and inequalities among different sectors in a domestic economy (e.g., progressive tax rate for small and medium enterprises, incentives for agricultural sector, incentives for start-up business).

Tax incentives have been defined in the literature as "measures that provide for a more favorable tax treatment of certain activities or sectors compared to what is

\footnotetext{
${ }^{11}$ OECD (2015) Countering harmful tax practices more effectively, taking into account transparency and substance, Action 5-2015 final report, OECD/G20 base erosion and profit shifting project. Available at https://doi.org/10.1787/9789264241190-en. Accessed 6 Nov 2019; Chaisse J, Ji X (2018) "Soft law" in international law-making: how soft international taxation law is reshaping international economic governance. Asian J WTO Law Health Pol 13(2):463-509
} 
granted to the general industry". ${ }^{12}$ International organizations have also defined tax incentives as "any special tax provisions granted to qualified investment projects or firms that provides favorable deviation from the general tax code". ${ }^{13}$ Examples of tax incentives are free trade zones, tax holidays, and compensation of losses (carry back/forward), among others. An overview of incentives introduced by countries to promote foreign direct investment is available in literature ${ }^{14}$ and reports from international organizations. ${ }^{15}$ Both definitions of tax incentives have the element of "favorable" treatment/deviation from tax rules which is one of the main elements to define a tax incentive, since in the absence of the incentive, the tax treatment will be the same as the one established in tax law.

Tax incentives can differ among developed and developing countries. Therefore, international organizations and scholars will also need to address these differences when drafting tax incentives. In general, developed countries aim to introduce tax incentives to promote export, research, and economic activities and to improve the overall position of domestic firms on global market. Examples are compensation of losses and tax incentives for research and development (including Intellectual Property Regimes).

Developing countries aim to introduce tax incentives to improve the development of certain regions (underdeveloped regions or rural areas) or specific sectors (natural resources (oil, mineral resources), plantation (agriculture, land grabbing to guarantee food security), manufacturing, financial sector (banks and financial institutions), intellectual property (information technology and biotechnology), tourism (hotel services, air and water transportation of tourist)).

Some of these tax incentives can be regarded as preferential tax regimes. Preferential regimes aim to attract investment to certain sectors of the economy or certain geographic areas or to make the country attractive as a business hub for other countries within the region (see section "Tax Incentives Regarded as Preferential Tax Regimes" below).

\footnotetext{
${ }^{12}$ Klemm A (2010) Causes, benefits and risks of tax incentives. Int Tax Public Financ 17(3):315-336

${ }^{13} \mathrm{IMF}$, OECD, UN et al (2015) Options for low income countries' effective and efficient use of tax incentives for investment: a report to the G-20 development working group by the IMF, OECD, UN and World Bank, p 8. Available at https://doi.org/10.1596/22923. Accessed 6 Nov 2019

${ }^{14}$ Tavares-Lehmann A, Toledano P, Johnson L et al (eds) (2016) Rethinking investment incentives. Trends and policy options. Columbia University Press, New York; Chaisse J (2015) Investor-state arbitration in international tax dispute resolution - a cut above dedicated tax dispute resolution? Virginia Tax Rev 41(2):149-222

${ }^{15}$ UNCTAD (2000) Tax incentives and foreign direct investment. A global survey. ASIT advisory studies no 16 UNCTAD/ITE/IPC/Misch.3. Available at https://unctad.org/en/Docs/iteipcmisc3_en. pdf Accessed 6 Nov 2019
} 


\section{Tax Incentives in Developing Countries to Attract FDI}

International organizations and scholars have been addressing the use of tax incentives to attract foreign direct investment for developing countries. For instance, by providing a comparison of type of tax incentives in a specific region (MENA-OECD Investment Programme); by addressing the influence of tax incentives in FDI in developing countries $^{16}$; and the relationship between tax incentives and international investment agreements. ${ }^{17}$

Developing countries have switched from only receiving foreign aid (official development assistance (ODA)) to introducing opportunities to enhance foreign investment. However, foreign investment is also dependent on other nontax factors such as good infrastructure, stable political and economic environment, and legal certainty for investors among others. Therefore, the tax incentives may not achieve the desired result if the nontax factors are weak or unstable, creating risks for foreign investors that may not be compensated by the tax incentive. ${ }^{18}$

Another challenge for developing countries is how to find the right balance between attracting foreign direct investment and controlling the investment. For this purpose, countries (i) have introduced provisions in the investment law or income tax law to address the incentives; (ii) have created administrative agencies (either one-stop-shop agencies or sectoral agencies) to provide information to the foreign investor and to facilitate that the foreign investor complies with the necessary legal, environmental, and tax requirements before carrying out the investment; and (iii) have introduced other requirements (e.g., capitalization requirements, environmental protection, export targets, performance requirement, requirement for local equity participation, employment of local staff, and transfer of technology among others).

Despite these changes, in practice, the number of laws and the discretionary power of the administrative agencies/ministry can also result in an obstacle for the foreign investor. If one example can illustrate this, it is the Philippines that has

\footnotetext{
${ }^{16}$ Andersen MR, Kett BR, von Uexkull E (2017) Corporate tax incentives and FDI in developing countries. In World Bank (ed) Global investment competitiveness report 2017/2018: foreign investors perspectives and policy implications. Available at https://doi.org/10.1596/978-1-46481175-3. Accessed 6 Nov 2019

${ }^{17}$ UNCTAD (2004) Incentives: UNCTAD series on issues in international investment agreements. Available at https://unctad.org/en/Docs/iteiit20035_en.pdf. Accessed 6 Nov 2019

${ }^{18}$ Leavy B (1984) Assessing country risk for foreign investment decisions. Long Range Plan 17(3):141-150. Available at https://doi.org/10.1016/0024-6301(84)90017-7. Accessed 6 Nov 2019; Chase C, Kuhle J, Walther C (1988) The relevance of political risk in direct foreign investment. Manag Int Rev 28(3):31-38; Dreyhaupt S, Nimac I, Hornberger K (2012) Political risk: the missing link in understanding investment climate reform? Invest Clim Pract 20:1-8. Available at http://documents.worldbank.org/curated/en/351251468336718273/pdf/ 682950NEWS0Inv00Box367908B00PUBLIC0.pdf. Accessed 6 Nov 2019
} 
17 investment promotion agencies in charge of granting incentives. ${ }^{19}$ This is currently under review in the Comprehensive Strategic Reform Program. ${ }^{20}$

In addition to the tax incentives, some developing countries have stabilization clauses/agreements concluded with the foreign investor that may limit the power of the country to levy taxes or to repeal the incentive. ${ }^{21}$ In a nutshell, these clauses/ agreements guarantee that legislative changes will not apply to the investor for the period established in such clause/agreement (e.g., 5, 10, 20 years). Literature in the topic is scarce, and the content of these clauses/agreements is not publicly available in most developing countries. ${ }^{22}$ These clauses/agreements may also result in tax base erosion and more discretionary power to the government and less transparency and accountability. ${ }^{23}$ The Toolkit on Tax Incentives also addressed the use of these clauses and the distortions for investment stating that "Such stability provisions, however, create an uneven playing field between old and new investors and can lead to significant distortions. Such situations should not last for too long. Government might therefore need to renegotiate existing incentive provisions or provide reasonable, time-bound incentives to new investors". ${ }^{24}$

To address these clauses in the extractive sector where these clauses/agreements are frequent, a new program by the Intergovernmental Forum on Mining (IGF) and the OECD on tax base erosion and profit shifting in the mining sector has started. This program also addresses the use of tax incentives in the mining industry and has drafted a toolkit so that governments of resource-rich countries are better equipped to identify and cost potential behavioral responses by mining investors to tax incentives. ${ }^{25}$ The BEPS Project will be further discussed in the following section.

\footnotetext{
${ }^{19}$ OECD (2016) Investment policy reviews: Philippines, p 24. Available at https://doi.org/10.1787/ 19900910 Accessed 6 Nov 2019

${ }^{20}$ Mosquera Valderrama IJ, Balhárova M (2020) Tax incentives in developing countries after BEPS: a case study: Singapore and Philippines. In: Mosquera Valderrama I, Lesage D, Lips W (eds) Taxation, international cooperation and the 2030 sustainable development agenda. Springer United Nations University Series on Regionalism, forthcoming

${ }^{21}$ Examples of such countries in Latin America are Chile, Colombia, Peru, Ghana, South Africa, and Zambia.

${ }^{22}$ One exception is Colombia that until 2013 published the stability contracts in the website of the Government. See http://www.mincit.gov.co/minindustria/temas-de-interes/contratos-de-estabilidadjuridica

${ }^{23}$ Mosquera Valderrama IJ (2015) The OECD-BEPS measures to deal with aggressive tax planning in South America and Sub-Saharan Africa: the challenges ahead. Intertax 43(10):615-627

${ }^{24} \mathrm{IMF}, \mathrm{OECD}$, UN et al (2015) Options for low income countries' effective and efficient use of tax incentives for investment: a report to the G-20 development working group by the IMF, OECD, UN and World Bank, p 29. Available at https://doi.org/10.1596/22923. Accessed 6 Nov 2019

${ }^{25}$ Intergovernmental Forum on Mining IGF-OECD (2018) The hidden cost of tax incentives in mining. IGF-OECD Program to Address BEPS in mining. Consultation Draft. Available at http:// www.oecd.org/tax/beps/hidden-cost-of-tax-incentives-in-mining-draft-toolkit-oecd-igf.pdf. Accessed 6 Nov 2019
} 


\section{Challenges Following the BEPS Project}

The OECD with the political mandate of the G20 introduced the project to tackle base erosion and profit shifting (BEPS) by multinationals. Developed and developing countries participate in this project by committing to implement the BEPS 4 Minimum Standards. One of these minimum standards is BEPS Action 5 that evaluates tax incentives in the form of preferential tax regimes that provide benefits to geographically mobile business income. In light of these international tax developments, sections "BEPS Project" and "BEPS Action 5" introduce the BEPS Project and BEPS Action 5 and their application to tax incentives. Thereafter, section "Tax Incentives in Developing Countries After BEPS" addresses the main findings in the literature and reports from international and regional (tax) organizations regarding the usefulness of tax incentives in developing countries after BEPS.

\section{BEPS Project}

The OECD-G20 Base Erosion Profit Shifting (BEPS) Project and its Inclusive Framework provide for the introduction of BEPS 4 Minimum Standards to which 135 jurisdictions have committed (November 2019). With the BEPS Inclusive Framework, countries including developing countries have been invited to participate on equal footing in the implementation, monitoring, and peer review of the four Minimum Standards.

One of the minimum standards is BEPS Action 5 which aims to identify preferential tax regimes that can qualify as harmful tax practices. ${ }^{26}$ These regimes are revised under the peer review of BEPS Action 5 undertaken by the Forum on Harmful Tax Practices ("FHTP"). The FHTP was created by the OECD in 1998 to monitor the implementation of the measures and guidelines addressed in the 1998 OECD Report on Harmful Tax Competition, ${ }^{27}$ but with the BEPS 4 Minimum Standards, the FHTP has revamped its work mainly by reviewing BEPS Action 5. The following paragraphs will introduce the main changes to tax incentives following the peer review of BEPS Action 5.

\footnotetext{
${ }^{26}$ Chaisse J (2016) International investment law and taxation: from coexistence to cooperation. World Economic Forum (WEF) think piece - E15initiative. Available at https://www.ictsd.org/ themes/global-economic-governance/research/international-investment-law-and-taxation-from

${ }^{27}$ OECD (1998) Harmful tax competition: an emerging global issue. Available at https://doi.org/ 10.1787/9789264162945-en. Accessed 6 Nov 2019
} 


\section{BEPS Action 5}

\section{Tax Incentives Regarded as Preferential Tax Regimes}

BEPS Action 5 deals with tax incentives regarded as preferential tax regimes to assess whether these regimes can be regarded as harmful tax practices. The form that these incentives can take place differs among countries, but some examples are, for instance, headquarter regimes, special economic zones (including free trade zones), regimes to foster sharing of technological developments (IP regimes), and regimes for specific sectors of the economy (e.g., financing and leasing, banking and insurance, distribution center and service center, shipping, holding company and fund management regimes).

Even though only one specific reference was made to the wording "tax incentives" in the content of BEPS Action 5 (i.e., for research and development), ${ }^{28}$ countries are also being reviewed in their tax incentives in the form of preferential tax regimes for geographically mobile business income. The content of BEPS Action 5 is based to a great extent on the 1998 OECD Report on Harmful Tax Competition (1998 OECD Report) published by the OECD Forum on Harmful Tax Practices (FHTP). ${ }^{29,30}$

\section{Peer Review by the FHTP of Preferential Tax Regimes}

Since the introduction of the BEPS Project, more than 287 tax regimes have been reviewed by the FHTP. Countries have amended their regimes following the OECD recommendations. The 2018 progress report of Action 5, some regimes have been placed under review (Dominican Republic, Jamaica, Morocco, Qatar), other regimes have been abolished (Cabo Verde, Malaysia, Mongolia, Morocco), and three regimes were amended to remove the potentially harmful features (Cabo Verde, Malaysia, Mauritius). ${ }^{31}$

The FHTP has reviewed tax incentives in the form of preferential tax regimes in the jurisdictions participating in the BEPS Inclusive Framework. The FHTP has also reviewed countries outside the Inclusive Framework. One example is the Philippines which Regional Area Headquarters and Regional Operating Headquarters were

\footnotetext{
${ }^{28}$ OECD (2015) Countering harmful tax practices more effectively, taking into account transparency and substance, Action 5-2015 final report, $\mathrm{OECD} / \mathrm{G} 20$ base erosion and profit shifting project, p 24. Available at https://doi.org/10.1787/9789264241190-en. Accessed 6 Nov 2019

${ }^{29}$ The Forum on Harmful Tax Practices (FHTP) is the body that has the mandate to monitor and review tax practices of jurisdictions around the world, focusing on the features of preferential tax regimes. Under the BEPS Project, the FHTP revamped its work, reviewing preferential regimes of all OECD and G20 members, with a priority on enhancing transparency and requiring substantial activities in preferential regimes (OECD 1998, 2017).

${ }^{30}$ OECD (1998) Harmful tax competition: an emerging global issue. Available at https://doi.org/ 10.1787/9789264162945-en. Accessed 6 Nov 2019

${ }^{31}$ OECD (2019) Harmful tax practices - 2018 progress report on preferential regimes: inclusive framework on BEPS: Action 5, OECD/G20 base erosion and profit shifting project. Available at https://doi.org/10.1787/9789264311480-en. Accessed 6 Nov 2019
} 
reviewed by the FHTP in the 2018 peer review report. This report stated that the Regional Area Headquarters was out of scope since it did not apply to mobile activities, while the Regional Operating Headquarters has some potential harmful features. As a result of the peer review report, this regime is currently in the process of being eliminated. ${ }^{32}$

\section{Framework for Peer Review by the FHTP}

The 1998 OECD Harmful Tax Practices report has been used as a framework for determining whether a regime is a preferential tax regime. ${ }^{33}$ Based on the 1998 Report, the OECD BEPS Action 5 tackles preferential tax regimes which can be used for artificial profit shifting and therefore "have the potential unfairly erode the tax bases of other countries, potentially distorting the location of capital and services". 34

The main elements in the 1998 Report are the following:

Key factors:

1. The regime imposes no or low effective tax rates on income.

2. The regime is ring-fenced from the domestic economy. A "Ring-fencing may take a number of forms, including: (i) a regime may explicitly or implicitly exclude resident taxpayers from taking advantage of its benefits, (ii) enterprises which benefit from the regime may be explicitly or implicitly prohibited from operating in the domestic market". ${ }^{35}$

3. The regime lacks transparency, e.g., favorable application of laws and regulations, negotiable tax provisions, and a failure to make widely available administrative practices.

4. There is no effective exchange of information (EOI) in relation to taxpayers benefiting from the operation of a preferential tax regime.

Other factors:

5. An artificial definition of the tax base: "applicable to rules that allow costs to be deducted even though the corresponding income is not taxable, rules allowing deductions for deemed expenses that are not actually incurred, and rules that permit overly generous reserve charges or that otherwise restrict the tax base for particular operations."

6. Failure to adhere to international transfer pricing principles (i.e., arm's length).

\footnotetext{
${ }^{32}$ Ibid., p. 24

${ }^{33}$ OECD (1998) Harmful tax competition: an emerging global issue. Available at https://doi.org/ 10.1787/9789264162945-en. Accessed 6 Nov 2019

${ }^{34} \mathrm{OECD}$ (2015) Countering harmful tax practices more effectively, taking into account transparency and substance, Action 5-2015 final report, OECD/G20 base erosion and profit shifting project, p 11. Available at https://doi.org/10.1787/9789264241190-en. Accessed 6 Nov 2019

${ }^{35}$ OECD (2019) Harmful tax practices - 2018 progress report on preferential regimes: inclusive framework on BEPS: Action 5, OECD/G20 base erosion and profit shifting project, p 27. Available at https://doi.org/10.1787/9789264311480-en. Accessed 6 Nov 2019
} 
7. Foreign source income exempt from residence country tax (i.e., territorial system). Encourages the location of activities for tax rather than business purposes.

8. Negotiable tax rate or tax base.

9. Existence of secrecy provisions whether because of bank secrecy, anonymous debt instruments, or bearer shares.

10. Access to a wide network of tax treaties.

11. The regime is promoted as a tax minimization vehicle.

12. The regime encourages operations or arrangements that are purely tax-driven and involve no substantial activities.

Some of these elements have been repealed (no. 10 access to a wide network of tax treaties and no. 11 the regime is promoted as a tax minimization vehicle) or revisited (no. 12 substantial activities has become a key factor) in the 2018 Progress Report. ${ }^{36}$ However, it is not clear for developing countries how these requirements need to be met, and there are no terms of reference to further explain these criteria and their application to the tax regimes currently introduced by a country.

In BEPS Action 5, the OECD when referring to the 1998 Report states that "in order for a regime to be considered preferential, it must offer some form of tax preference in comparison with the general principles of taxation in the relevant country". ${ }^{37}$ Therefore, a tax incentive can be regarded as harmful if the tax incentive provides for reduction in the tax rate or reduction in the tax base for investors, for instance, in the case of IP regimes, free trade zones, etc. However, in order to determine the benefit (in the rate or base), reference will need to be made to the tax system of the country and not to other countries; "for example, where the rate of corporate tax applied to all income in a particular country is $10 \%$, the taxation of income from mobile activities at $10 \%$ is not preferential, even though it may be lower than the rate applied in other countries". ${ }^{38}$ In short, the analysis on whether a tax regime is preferential should be on a case-by-case basis (per incentive and per country).

In addition, BEPS Action 5 requires a substantial activity that is also based on the 1998 Report. According to Action 5, this factor looks at whether a regime "encourages purely tax-driven operations or arrangements" and states that "many harmful preferential tax regimes are designed in a way that allows taxpayers to derive benefits from the regime while engaging in operations that are purely tax-driven

\footnotetext{
${ }^{36}$ OECD (2019) Harmful tax practices - 2018 progress report on preferential regimes: inclusive framework on BEPS: Action 5, OECD/G20 base erosion and profit shifting project, pp 34-40. Available at https://doi.org/10.1787/9789264311480-en. Accessed 6 Nov 2019

${ }^{37} \mathrm{OECD}$ (2015) Countering harmful tax practices more effectively, taking into account transparency and substance, Action 5-2015 final report, $\mathrm{OECD} / \mathrm{G} 20$ base erosion and profit shifting project, p 19. Available at https://doi.org/10.1787/9789264241190-en. Accessed 6 Nov 2019

${ }^{38}$ OECD (2015) Countering harmful tax practices more effectively, taking into account transparency and substance, Action 5-2015 final report, $\mathrm{OECD} / \mathrm{G} 20$ base erosion and profit shifting project, p 20. Available at https://doi.org/10.1787/9789264241190-en. Accessed 6 Nov 2019
} 
and involve no substantial activities". 39 This is, for instance, the case where there is no link (legal/economic) to the country.

The analysis of the application of these criteria to BEPS Action 5 and the 1998 criteria to tax incentives has been carried out elsewhere. ${ }^{40}$ Some of these criteria (no. 4 effective EOI and no. 6 transfer pricing principles) are no longer useful. The reason is the wide use by countries of the OECD Transfer Pricing Guidelines, the introduction in 2009 of a global standard of exchange of information (EOI) on request and the creation of the Global Transparency Forum, and the introduction in 2013 of the Common Reporting Standard on Automatic Exchange of Financial Account Information. As of November 2019, 106 countries have signed the Common Reporting Standard, and 158 countries are members of the Global Transparency Forum.

\section{Tax Incentives in Developing Countries After BEPS}

\section{Literature}

The analysis of the application of BEPS Action 5 to developing countries has been addressed in the literature with an overall analysis ${ }^{41}$ and more specific country analysis $\left(\right.$ Botswana $^{42}$ Egypt $^{43}$ ). These authors have expressed their concerns in the use of BEPS Actions on tax incentives for developing countries and the problems that the use of these incentives will create in tax competition. Since developing countries need to attract investment, one of the concerns of these countries is that the application of BEPS Action 5 will create more obstacles for these countries to draft their own tax incentive policy which will be limited by the framework of peer review of BEPS Action 5.44

\footnotetext{
${ }^{39}$ OECD (2015) Countering harmful tax practices more effectively, taking into account transparency and substance, Action 5-2015 final report, $\mathrm{OECD} / \mathrm{G} 20$ base erosion and profit shifting project, p 23. Available at https://doi.org/10.1787/9789264241190-en. Accessed 6 Nov 2019

${ }^{40}$ Mosquera Valderrama IJ (2020) Regulatory framework for tax incentives in developing countries after BEPS Action 5. Intertax Special Issue. Kluwer Publications, forthcoming

${ }^{41}$ Mosquera Valderrama IJ (2019) The EU standard of good governance in tax matters for third (non-EU) countries. Intertax 47(5):454-467; Keen M (2018) Competition, coordination and avoidance in international taxation. Bull Intl Taxn 72(4/5):220-225; Bjerkesteun HM, Wille HG (2016) Tax holidays in a BEPS perspective. Intertax 43(1):106-120; Bal AM (2014) Tax incentives: ill-advised tax policy or growth catalysts? Eur Taxn 54(2/3):63-70

${ }^{42}$ Masuku-Chimbombi AR (2018) The legal framework of the Botswana special tax zone: the SPEDU region and Action 5 of the OECD/G20 base erosion and profit shifting initiative. Bull Intl Taxn 78(10):379-386

${ }^{43}$ Abdellatif MM, Tran-Nam B (2016) The tax policy debate regarding tax incentives in developing countries: the case of targeted tax incentives in Egypt. Bull Intl Taxn 70(7):379-386

${ }^{44}$ Mosquera Valderrama IJ (2020) Regulatory framework for tax incentives in developing countries after BEPS Action 5. Intertax Special Issue. Kluwer Publications, forthcoming
} 


\section{International and Regional (Tax) Organizations}

International organizations (IMF, OECD, UN, and WB), regional organizations (i.e., ADB), and regional tax organizations (i.e., CIAT and ATAF) have addressed the use of tax incentives in developing countries (low-income countries). Four important sources are the (a) Toolkit on Tax Incentives published by the Platform on Collaboration on $\mathrm{Tax}^{45}$; (b) the document: Design and Assessment of Tax Incentives in Developing Countries published by the United Nations and CIAT ${ }^{46}$; (c) the 2013 OECD-ATAF document in Exchange of Information for Developing Countries ${ }^{47}$; and (d) the 2018 Asian Development Bank Report on Tax and Development. ${ }^{48}$

Countries and international and regional tax organizations are questioning (i) whether tax incentives generate the desired economic growth and social development and (ii) whether tax incentives erode the tax base without having actual effects on the level of investment in the country. Therefore, the focus is no longer only on tax incentives as the methods of attracting investment but also on the impact they have on countries' economies. ${ }^{49}$

However, the recommendations and analysis of the tax incentives differ among international and regional organizations. For instance, even though the 2015 Toolkit $^{50}$ and the $2018 \mathrm{UN}-\mathrm{CIAT}^{51}$ recommended an economic analysis to prevent the use of "wasteful" tax incentives, the analysis of the Toolkit has more an economic approach since it focuses on effectiveness and efficiency, whereas the 2018 UN-CIAT $^{52}$ focuses not only on the cost-benefit analysis but also on legal

\footnotetext{
${ }^{45} \mathrm{IMF}, \mathrm{OECD}$, UN et al (2015) Options for low income countries' effective and efficient use of tax incentives for investment: a report to the G-20 development working group by the IMF, OECD, UN and World Bank. Available at https://doi.org/10.1596/22923. Accessed 6 Nov 2019

${ }^{46} \mathrm{UN}-\mathrm{CIAT}$ (2018) Design and assessment of tax incentives in developing countries: selected issues and a country experience, iii. Available at https://www.ciat.org/Biblioteca/Estudios/2018_design assessment tax incentives_UN_CIAT.pdf. Accessed 6 Nov 2019

${ }^{47} \mathrm{OECD}-\mathrm{ATAF}$ (2013) A practical guide for exchange of information for developing countries. Available at http://www.oecd.org/tax/tax-global/practical_guide_exchange_of_information.pdf Accessed 6 Nov 2019

${ }^{48}$ Asian Development Bank (ADB) (2018) Tax and development: challenges in Asia and the Pacific. In: Araki S, Nakabayashi S (eds). Available at https:/www.adb.org/sites/default/files/ publication/456486/adbi-tax-and-development-challenges-asia-pacific.pdf. Accessed 6 Nov 2019

${ }^{49} \mathrm{IMF}, \mathrm{OECD}, \mathrm{UN}$ et al (2015) Options for low income countries' effective and efficient use of tax incentives for investment: a report to the G-20 development working group by the IMF, OECD, UN and World Bank. Available at https://doi.org/10.1596/22923. Accessed 6 Nov 2019; UN-CIAT (2018) Design and assessment of tax incentives in developing countries: selected issues and a country experience, iii. Available at https://www.ciat.org/Biblioteca/Estudios/2018_design_assess ment_tax_incentives_UN_CIAT.pdf. Accessed 6 Nov 2019

${ }^{50}$ IMF, OECD, UN et al (2015) Options for low income countries' effective and efficient use of tax incentives for investment: a report to the G-20 development working group by the IMF, OECD, UN and World Bank. Available at https://doi.org/10.1596/22923. Accessed 6 Nov 2019

${ }^{51}$ UN-CIAT (2018) Design and assessment of tax incentives in developing countries: selected issues and a country experience, iii. Available at https://www.ciat.org/Biblioteca/Estudios/2018_design_ assessment_tax_incentives_UN_CIAT.pdf. Accessed 6 Nov 2019

${ }^{52} \mathrm{Ibid}$.
} 
drafting of tax incentives from an income tax law perspective. ${ }^{53}$ The focus of the Asian development bank is regional cooperation and the need of transparency in the drafting of tax incentives, whereas the OECD-ATAF ${ }^{54}$ focuses on exchange of information to detect the potential abuse of tax incentives in developing countries.

\section{Toolkit on Tax Incentives}

In the 2015 Toolkit on Tax Incentives for Low-Income Countries, the OECD, the IMF, the World Bank, and the UN stated that "Tax incentives generally rank low in investment climate surveys in low-income countries, and there are many examples in which they are reported to be redundant-that is, investment would have been undertaken even without them. And their fiscal cost can be high, reducing opportunities for much-needed public spending on infrastructure, public services or social support, or requiring higher taxes on other activities". ${ }^{55}$

Therefore, these organizations provided recommendations to low-income countries to improve the effectiveness and efficiency of their investment tax incentives. Some of these recommendations are:

At the national level, (i) to improve the design of tax incentives (e.g., by placing greater emphasis on cost-based incentives rather than profit-based ones; and (ii) by targeting tax incentives better), (iii) strengthen their governance (for instance, through more transparency, better tax laws, and a stronger role of the Minister of Finance), and (iv) by undertaking more systematic evaluations. At the international level, countries may gain by coordinating their tax incentive policies regionally, so as to mitigate the negative spillovers from tax competition.

In addition, these international organizations introduce two elements for evaluation of tax incentives: effectiveness and efficiency. According to the 2015 Toolkit, to assess effectiveness of a tax incentive, three factors need to be analyzed: (1) size of the net investment effect, (2) net impact of higher investment on jobs and wages, and (3) productivity spillovers. ${ }^{56}$ Although theoretically straightforward, it is rather difficult to assess how much investment was attracted purely because of the incentive. It is unclear if a tax incentive has any impact on the level of investment committed at all. Net impact of higher investment on jobs and wages looks at the number of jobs created or in cases where the new jobs replaced old ones, at the increase in wages. The rationale is that the new investment can attract supplying and competing firms, and as a result it can boost economic activity. This positive effect is

\footnotetext{
${ }^{53}$ Ibid., pp. $37-76$

${ }^{54}$ OECD-ATAF (2013) A practical guide for exchange of information for developing countries. Available at http://www.oecd.org/tax/tax-global/practical_guide_exchange_of_information.pdf Accessed 6 Nov 2019

${ }^{55} \mathrm{IMF}$, OECD, UN et al (2015) Options for low income countries' effective and efficient use of tax incentives for investment: a report to the G-20 development working group by the IMF, OECD, UN and World Bank, p 3. Available at https://doi.org/10.1596/22923. Accessed 6 Nov 2019

${ }^{56} \mathrm{IMF}, \mathrm{OECD}$, UN et al (2015) Options for low income countries' effective and efficient use of tax incentives for investment: a report to the G-20 development working group by the IMF, OECD, UN and World Bank, p 11. Available at https://doi.org/10.1596/22923. Accessed 6 Nov 2019
} 
referred to as "productivity spillover." Although the theory for testing the effectiveness of incentives is covered in a number of publications, the actual analysis remains tricky. The monitoring needed to carry out the analysis also requires a lot of resources, which the developing countries often lack.

The toolkit lists four factors to be considered when assessing the social cost or efficiency of a tax incentive: (1) net public revenue losses, (2) administrative and compliance costs, (3) scarcity of public funds, and (4) distorted resource allocation. ${ }^{57}$ Net public revenue losses take into consideration the forgone revenue that was not collected as a result of the incentives - whether it is tax holiday or lower tax rate. The rationale behind assessing the cost of the incentive is that the country is devoting part of its budget, which could otherwise be used for public spending. This is also a strong argument why tax incentives should have the objective of creating a social and economic benefit for the country and its residents.

\section{UN-CIAT Design and Assessment of Tax Incentives}

In 2018, a study by the United Nations and the CIAT (Inter-American Centre Tax Administrations) was published addressing the design and assessment of tax incentives in developing countries with a case study of the Dominican Republic. ${ }^{58}$ In addition, a specific checklist for drafting tax incentive legislation and a cost-benefit analysis framework for assessing tax incentives were introduced. This report did not address the application of BEPS Action 5 checklist to tax incentives.

The starting point of this study is that "tax incentives are a useful tool for attracting investments that would not have been made without the provision of tax benefits" ${ }^{59}$ However, this study recommends developing countries to "bring the corporate tax rate regime closer to international practice and to correct the deficiencies rather than provide investors with additional tax benefits". ${ }^{60}$

Regarding the deficiencies, this report stated that it is sometimes easier for countries to provide tax incentives than to correct deficiencies in the design of the tax system or inadequate physical, financial, legal, or institutional infrastructure. Examples of some of the deficiencies are, for instance, (i) developing countries may have higher corporate tax rate and several tax incentives (tax rate reduction or exemption) for several sectors (e.g., tourism, financial sector), (ii) developing countries may grant incentives in a discretionary way in the form of tax incentive or a stabilization agreement, and (iii) developing countries may encounter problems of corruption and lack of transparency in the application of these incentives.

\footnotetext{
${ }^{57} \mathrm{IMF}, \mathrm{OECD}, \mathrm{UN}$ et al (2015) Options for low income countries' effective and efficient use of tax incentives for investment: a report to the G-20 development working group by the IMF, OECD, UN and World Bank, p 10. Available at https://doi.org/10.1596/22923. Accessed 6 Nov 2019

${ }^{58} \mathrm{UN}-\mathrm{CIAT}$ (2018) Design and assessment of tax incentives in developing countries: selected issues and a country experience, iii. Available at https://www.ciat.org/Biblioteca/Estudios/2018_design_ assessment_tax_incentives_UN_CIAT.pdf. Accessed 6 Nov 2019

${ }^{59}$ Ibid., p. 13

${ }^{60}$ Ibid., p. 7
} 
Therefore, this report recommended to countries (i) to carry out a cost-benefit analysis for each tax incentive. The costs of the incentives are mainly revenue costs, resource allocation costs, enforcement and compliance costs, and costs associated with corruption and lack of transparency ${ }^{61}$ The benefits of the tax incentives are correction of market inefficiencies or generation of positive externalities ${ }^{62}$ (ii) and to make use of the report's checklist for drafting tax incentives legislation. The aim of this checklist is "to serve as a list of things that should be considered and addressed when drafting a tax incentive so as to maximise clarity of scope and administration. It seeks to ensure that the legal drafting of a tax incentive is as consistent as possible with the policy underlying the tax incentive". ${ }^{63}$

Finally, regarding the use of specific targeting regimes including sectorial targeting regimes, this report stated that these regimes have "many advantages, such as restricting the benefits of the incentives to those types of investment that policymakers consider to be most desirable and making it possible to target those sectors that are most likely to be influenced by tax considerations. Among the sectors of the economy and types of activities commonly preferred are manufacturing activities and pioneer industries, as well as export promotion, locational incentives and investments that result in significant transfers of technology". ${ }^{64}$

\section{OECD-ATAF: Exchange of Information for Developing Countries}

Another regional tax organization, i.e., ATAF, has published, together with the OECD, a document targeted at foreign direct investment and addressing the use of exchange of information to detect the potential abuse of tax incentives.

Some of the findings in this document are that "many developing countries have tax incentives to attract foreign direct investment or promote exports. Tax revenues may be lost as some investors may improperly claim incentives or shift income from related taxable firms to those qualifying for favourable tax treatment. Tax incentive programmes may be open to abuse from tax avoidance schemes. Exchange of information may assist in identifying these abuses. Example: the tax administration suspects that a domestic company re-labels domestic investment as foreign direct investment or that it sells businesses to foreign subsidiaries disguised as new investors in order to take advantage of tax incentives targeted at foreign direct investment. A request for information to the country of the foreign subsidiary may assist in determining that the investment does not qualify to benefit from the tax incentive". 65

\footnotetext{
${ }^{61}$ Ibid., p. 15, 77-91

${ }^{62}$ Ibid., p. 13, 77-91

${ }^{63}$ Ibid., pp. $37-76$

${ }^{64}$ Ibid., p. 21

${ }^{65}$ OECD-ATAF (2013) A practical guide for exchange of information for developing countries, $p$ 6. Available at http://www.oecd.org/tax/tax-global/practical_guide_exchange_of_information.pdf Accessed 6 Nov 2019
} 
More recently in a meeting organized in April 2019 by the IMF and the World Bank, ATAF representative referred to the challenges of BEPS in Africa including the weak domestic legislation, the limited capacity of the tax administration, and the excessive tax incentives among others. ${ }^{66}$

\section{Asian Development Bank: Tax and Development}

For developing countries in Asia, a 2018 study by the Asian Development Bank on Tax and Development addressed the OECD developments EOI and BEPS stating that the "emphasis for developing countries in Asia has often felt like external pressure to make important legislation changes and implement new processes and organizational structures - issues that are challenging even in more developed countries with mature tax administrations. A degree of resistance to international standards is therefore understandable. The regional strategic workshops in ADB's program have enabled some countries to move more quickly in making the decisions to adopt the standards and become active members of the Global Forum on Transparency and Exchange of Information and more recently the Inclusive Framework on BEPS". 67

More specifically, regarding tax incentives, this study addressed the need of transparency in the drafting of tax incentives stating that "transparent and reliable tax administration is also one of the elements of a good business environment. Tax incentives should be controlled by the Ministry of Finance. If they are managed by the Investment Board or ministries to promote FDI, tax incentives proliferate and can become too complex at the expense of government coffers". ${ }^{68}$ For this purpose, the Asian Development Bank will carry out work to create a better Revenue Policy in Asian countries by enhancing "broad based, simple, fair, comprehensive, and revenue-neutral systems by revising existing taxes or introducing new taxes, improved quality of tax legislation and regulations, and curbing wasteful tax incentives". 69

\footnotetext{
${ }^{66}$ See Baine M (2019) Key international corporate tax challenges in the African Landscape. In: IMF and World Bank (eds) 2019 Spring meetings. Available at https:/www.brettonwoodsproject.org/ 2019/04/taxing-to-develop-international-taxation-challenges-for-africa/. Accessed 6 Nov 2019, presentation at the IMF/World Bank Spring Meetings Official Session Taxing to Develop: International Taxation Challenges for Africa.

${ }^{67}$ Asian Development Bank (ADB) (2018) Tax and development: challenges in Asia and the Pacific. In: Araki S, Nakabayashi S (eds), p 49. Available at https://www.adb.org/sites/default/ files/publication/456486/adbi-tax-and-development-challenges-asia-pacific.pdf. Accessed 6 Nov 2019

${ }^{68}$ Asian Development Bank (ADB) (2018) Tax and development: challenges in Asia and the Pacific. In: Araki S, Nakabayashi S (eds), p 12. Available at https://www.adb.org/sites/default/ files/publication/456486/adbi-tax-and-development-challenges-asia-pacific.pdf. Accessed 6 Nov 2019

${ }^{69}$ Asian Development Bank (ADB) (2018) Tax and development: challenges in Asia and the Pacific. In: Araki S, Nakabayashi S (eds), p 44. Available at https://www.adb.org/sites/default/ files/publication/456486/adbi-tax-and-development-challenges-asia-pacific.pdf. Accessed 6 Nov 2019
} 


\section{Challenges Following the Sustainable Development Goals}

The discussion of tax incentives has also taken place in light of the Sustainable Development Goals. These goals are now included in the 2030 Agenda, which for taxation also includes SDG targets 17.1: Strengthen domestic resource mobilization and 17.16 on global partnerships for sustainable development.

As stated in the 2018 Global Investment Competitiveness Report, "70 "for many developing countries, foreign direct investment (FDI) has become the largest source of external finance, surpassing official development assistance (ODA), remittances, or portfolio investment flows. In 2016, more than 40 percent of the nearly $\$ 1.75$ trillion of global FDI flows was directed to developing countries, providing muchneeded private capital. Yet the financing required to achieve the Sustainable Development Goals (SDGs) remains prohibitively large and largely unmet by current FDI inflows - especially in fragile and conflict-affected situations (FCS)". 7

As it has been argued in scholarship "developing countries face an economic dilemma when it comes to corporate taxation. On one hand, lower-income countries have a need for increased public revenues, for which the corporate income tax is one of the easier to admit taxes. On the other hand, there is a tangible pressure to limit corporate taxes - both through rate reduction and tax incentives - in order to attract foreign investments". ${ }^{72}$

Therefore, in drafting and evaluating tax incentives, developing countries should assess the effectiveness of tax incentives in light of the benefits that tax incentives want to achieve (social and economic growth) and the efficiency in light of the cost side in terms of revenues lost, fair taxation, and equal opportunities for all citizens. This is a more specific SDG evaluation approach that differs to some extend from the current literature by international and regional organizations on tax incentives. ${ }^{73}$ The proposed framework to evaluate tax incentives in developing countries is provided in the following section.

\footnotetext{
${ }^{70}$ World Bank (2018) Global investment competitiveness report 2017/2018: foreign investor perspectives and policy implications. World Bank Group, Washington, DC. Available at http:// documents.worldbank.org/curated/en/169531510741671962/Global-investment-competitivenessreport-2017-2018-foreign-investor-perspectives-and-policy-implications. Accessed 6 Nov 2019 ${ }^{71}$ Ibid., p. 1

${ }^{72}$ Mosquera Valderrama IJ, Lesage D, Lips W (2018) Tax and development: the link between international taxation, the base erosion profit shifting project and The 2030 sustainable development agenda. UNU-CRIS working paper no. W-2018/3, p 16, 22-23. Available at http://cris.unu.edu/ sites/cris.unu.edu/files/W-2018-4.pdf. Accessed 6 Nov 2019; Durst M (2018) Poverty, tax competition, and base erosion. Tax Notes Int 89(12):1189-1201

${ }^{73} \mathrm{IMF}, \mathrm{OECD}, \mathrm{UN}$ et al (2015) Options for low income countries' effective and efficient use of tax incentives for investment: a report to the G-20 development working group by the IMF, OECD, UN and World Bank. Available at https://doi.org/10.1596/22923. Accessed 6 Nov 2019; UN-CIAT (2018) Design and assessment of tax incentives in developing countries: selected issues and a country experience, iii. Available at https://www.ciat.org/Biblioteca/Estudios/2018_design_assess ment_tax_incentives_UN_CIAT.pdf. Accessed 6 Nov 2019
} 


\section{Conclusion: A Proposed Framework}

It has been argued in the past that "developing countries should re-evaluate their tax incentives, stability agreements (clauses), and the excessive number of free trade zones that they have, taking into consideration their usefulness in encouraging sustainable investment. Tax incentives in developing countries should also be re-evaluated to establish their benefit for the country, as such incentives often only result in tax base erosion. One of the risks of the extensive use of tax incentives and stability agreements is that enterprises may leave the country in question once the tax incentive or agreement is no longer available. However, this should not be dealt with in Action 5 but, rather, by adopting a regional approach that takes into account the needs of countries in a specific region and the design of tax incentives in a coordinate way to prevent unfair tax competition in the region". 74

In order to evaluate tax incentives in light of the Sustainable Development Goals, the proposed framework for analysis of tax incentives in developing countries should take into account the effectiveness of tax incentives in achieving their aims (social and economic growth) and then the cost side - their efficiency in terms of revenue loss, fair taxation, and equal opportunities for all citizens. The references to social and economic growth and also to fair taxation and equal opportunities are linked to the Sustainable Development Goals. These goals include achieving decent work in economic growth, eradication of poverty, and building resilient infrastructure. The governments have an important role in encouraging growth and development which also contribute to SDG targets 17.1: Strengthen domestic resource mobilization and 17.16 on global partnerships for sustainable development.

The elements for this proposed framework differ to some extent from the elements (see section "International and Regional (Tax) Organizations") provided by the Toolkit on Tax Incentives that provides a more economic analysis of effectiveness (size of the net investment effect, net impact of higher investment on jobs, and wages and productivity spillovers) ${ }^{75}$ and efficiency (net public revenue losses, administrative and compliance costs, scarcity of public funds, and distorted resource allocation). The elements of this proposed framework take into account some of the elements of the UN-CIAT cost-benefit analysis, mainly revenue costs and lack of transparency costs. ${ }^{76}$

This framework should be designed by each country, and if possible, taking into account the practice of other countries in the region so that countries can also exchange best practices. The following criteria can be used:

\footnotetext{
${ }^{74}$ Mosquera Valderrama IJ (2018) Output legitimacy deficits and the inclusive framework of the $\mathrm{OECD} / \mathrm{G} 20$ base erosion and profit shifting initiative. Bull Intl Taxn 72(3):160-170

${ }^{75} \mathrm{IMF}, \mathrm{OECD}$, UN et al (2015) Options for low income countries' effective and efficient use of tax incentives for investment: a report to the G-20 development working group by the IMF, OECD, UN and World Bank, p 32. Available at https://doi.org/10.1596/22923. Accessed 6 Nov 2019

${ }^{76} \mathrm{UN}-\mathrm{CIAT}$ (2018) Design and assessment of tax incentives in developing countries: selected issues and a country experience, iii, p 15. Available at https://www.ciat.org/Biblioteca/Estudios/2018_ design_assessment_tax_incentives_UN_CIAT.pdf. Accessed 6 Nov 2019
} 
- Each tax incentive should be reviewed in a systematic way. This evaluation should take place before and after the incentive is granted and at least every 2 years so that the incentive is evaluated on a regular basis instead of granting the incentive for 10, 20, or 30 years without any systematic evaluation. This evaluation should focus on whether the tax incentive has achieved the specific goals in terms of effectiveness and efficiency.

- The incentive should have a clear target and eligibility criteria for granting the incentive; this target should be measurable to achieve the social and economic development of the region/sector/country.

- There should be no room for administrative discretion on the granting of the incentive.

- The incentive should be transparent (publicly available in the website of the tax administration or administrative agency).

- For each incentive there should be a fiscal budget and perhaps also a ceiling in the budget so that once reached the ceiling of revenue loss, the tax incentive will be terminated. The amount of allocated budget used can be made available on a yearly basis to investors so that they are not surprised when the ceiling has been reached.

- To achieve greater accountability and transparency of tax incentives, it is important that the general tax expenditure of the country is periodically analyzed and tax budgets are implemented. ${ }^{77}$ This analysis requires monitoring and systematic evaluation, and efforts should be made by international organizations to train staff and use data analytics to carry out this analysis in developing countries.

The institutional conditions for these incentives should be also taken into account, mainly:

- Developing countries should appoint one person, typically the Ministry of Finance, to administer and monitor the tax incentives. This is often not the case, and administration is divided among multiple agencies dealing with that particular industry or region. ${ }^{78}$

- Introduction of tax incentives in the income tax law and/or investment law, but without using several laws or decrees where tax incentives can be found. The income tax law and/or investment law should be publicly available with a specific reference in English (to the incentive, the tax benefit, and the criteria used to systematically evaluate the tax incentive).

\footnotetext{
${ }^{77}$ UN-CIAT (2018) Design and assessment of tax incentives in developing countries: selected issues and a country experience, iii, p 19. Available at https://www.ciat.org/Biblioteca/Estudios/2018 design_assessment_tax_incentives_UN_CIAT.pdf. Accessed 6 Nov 2019

${ }^{78}$ Mosquera Valderrama IJ, Balhárova M (2020) Tax incentives in developing countries after BEPS: a case study: Singapore and Philippines. In: Mosquera Valderrama I, Lesage D, Lips W (eds) Taxation, international cooperation and the 2030 sustainable development agenda. Springer United Nations University Series on Regionalism, forthcoming
} 
- The stability contracts should be re-evaluated, and in any case all contracts should be published in the government website, with specific information on the type of contract, the tax benefit agreed under the contract, dispute resolution mechanisms, and also the responsible person to grant that agreement.

- The use of one-stop-shop agencies should be encouraged, since investors may find it useful to access the information but also in dealing with all permits/licenses and further questions regarding their investment. This agency should have a code of conduct to guide their activities within the agency, and in addition a list of sanctions (administrative fine or imprisonment) should be introduced. In case that there is any corruption or bribery, the sanction for the respective agency official should be made publicly available.

\section{Cross-References}

Achieving Sustainable Development Objectives in International Investment Law - Tax and Investment Treaties Interactions

Acknowledgements The writing and research carried out for this chapter is the result of the ERC research in the framework of the GLOBTAXGOV Project (2018-2023). The GLOBTAXGOV Project investigates international tax law making including the adoption of OECD and EU standards by 12 countries. The GLOBTAXGOV Project has received funding from the European Research Council (ERC) under the European Union's Seven Framework Programme (FP/2007-2013) (ERC Grant agreement n. 758671). 